\title{
Kewenangan Notaris Dalam Mengenali Pengguna Jasa dan Perlindungan Hukum Jika Terjadi Tindak Pidana Pencucian Uang
}

\author{
Nina Khadijah Maulidia1, Gde Made Swardhana² \\ ${ }^{1}$ Program Studi Magister (S2) Fakultas Hukum Universitas Udayana, E-mail: \\ ninakhadijah2388@gmail.com \\ 2 Fakultas Hukum Universitas Udayana, E-mail: gmswar@gmail.com
}

\begin{abstract}
Info Artikel
Masuk : 4 Februari 2020

Diterima : 9 Juli 2020

Terbit : 31 Juli 2020

Keywords :

Authorit; Service Users; Legal protection; notary; money laundering

Kata kunci:

Kewenangan; Pengguna Jasa, Perlindungan Hukum, TPPU

Corresponding Author:

Nina Khadijah, E-mail: ninakhadijah2388@gmail.com

DOI :

10.24843/AC.2020.v05.i02.p06
\end{abstract}

\begin{abstract}
The Act Number 2 of 2014 concerning Amendments to Law Number 30 of 2004 concerning the Position of Notary (hereinafter abbreviated as UUJNP) Article 16 paragraph (1) letters $(a)$ and $(f)$ determine that the notary in carrying out his obligations, must act trustfully, honestly, safeguard the interests of parties involved in legal actions, and keep the contents confidential deed as well as information obtained for making the deed, unless the law stipulates otherwise, while Regulation of the Minister of Law and Human Rights number 9 of 2017 (hereinafter abbreviated Permenkumham) Article 24 paragraph (2) specifies, that the notary is obliged to report to PPATK regarding the existence of a transaction finance conducted by service users. It appears that between these rules there is a norm conflict between UUJNP and Permenkum. The results of this study prove the fact that the notary is required to apply the principle of service users, consider there are nonconformities, or consider the facts of money laundering. The notary is also required to report users of the service to PPATK if requesting the transaction is suspected. Article 16 paragraph (1) Subparagraph $f$ of the UUJNP, because the actions taken have been regulated in Article 28 of the Law of the UUTTPU. Second, legal permission for a Notary regarding the notary summons for a case in court, then there must be prior approval of the Notary Honorary Council (MKN) in advance and the notary public can also use the right to deny if there is a support for the material or the contents of the deed.
\end{abstract}

\section{Abstrak}

Undang No. 2 Tahun 2014 Tentang Perubahan atas UndangUndang No. 30 tahun 2004 Tentang Jabatan Notaris (selanjutnya disingkat UUJNP) Pasal 16 ayat (1) huruf (a) dan (f) menentukan bahwa notaris dalam menjalankan kewajibannya, wajib bertindak amanah, jujur, menjaga kepentingan pihak yang terkait dalam perbuatan hukum, dan merahasiakan isi akta serta keterangan yang diperoleh untuk pembuatan akta, kecuali undang-undang menentukan lain, sedangkan Peraturan Menteri Hukum dan Hak Asasi Manusia nomor 9 tahun 2017 (selanjutnya disingkat Permenkumham) Pasal 24 ayat (2) menentukan, bahwa notaris wajib melaporkan kepada PPATK mengenai adanya transaksi keuangan yang dilakukan oleh 


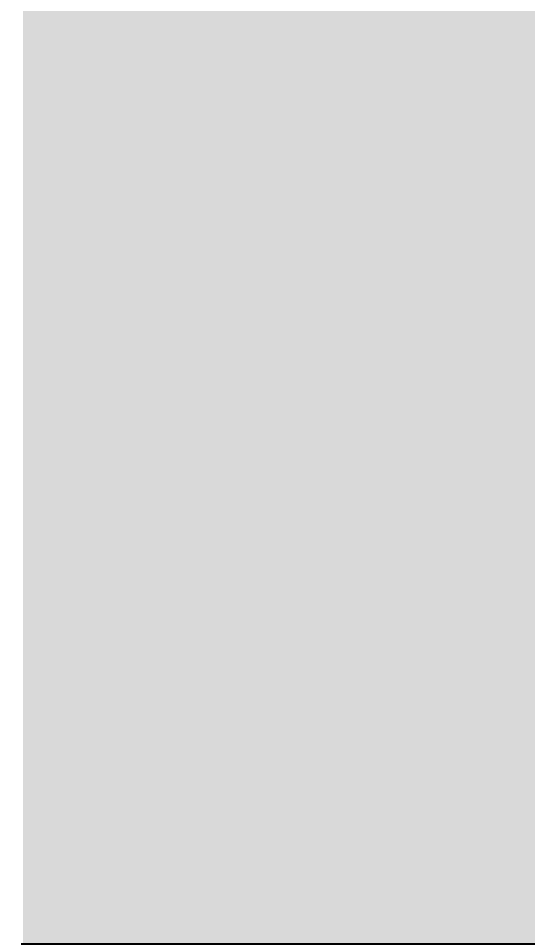

\begin{abstract}
pengguna jasa. Tampak antara aturan-aturan tersebut terjadi konflik norma antara UUJNP dan Permenkum. Inti pemasalahannya yaitu mengenai wewenang notaris dalam mengidentifikasi pengguna jasa yang diatur dalam Permenkumham dan upaya perlindungan notaris secara hukum apabila terjadi kejahatan pencucian uang oleh pengguna jasanya. Metode penelitian ini adalah penelitian hukum normatif dengan pendekatan perundang-undangan. Hasil penelitian ini menunjukkan bahwa notaris wajib menerapkan prinsip mengenali pengguna jasa, apabila ada ketidaksesuaian atau diduga adanya tindak pidana pencucian uang. Notaris juga wajib melaporkan pengguna jasa tersebut kepada PPATK jika diduga transaksi tersebut mencurigakan. Tindakan yang dilakukan notaris ini tidaklah melanggar ketentuan Pasal 16 ayat (1) hurup $f$ UUJNP, karena tindakan yang dilakukan tersebut telah diatur pada Pasal 28 UUTTPU. Kedua, perlindungan hukum kepada Notaris terkait pemanggilan notaris dalam perkara di pengadilan, maka harus ada persetujuan Majelis Kehormatan Notaris (MKN) terlebih dahulu dan juga notaris dapat menggunakan hak ingkar jika ada hubungannya dengan materi atau isi akta.
\end{abstract}

\title{
1. Pendahuluan
}

Notaris adalah pejabat umum yang memiliki kewenangan untuk membuat akta otentik. Akta yang dibuat Notaris berkedudukan penting sebagai upaya untuk mendapatkan kepastian hukum, dikarenakan akta tersebut tidak lagi memerlukan alat pembuktian lain dan juga sebagai salah satu alat untuk mendapatkan hak di dalam hukum ${ }^{1}$. Notaris merupakan profesi yang dilandasi ketentuan, Pasal 1 UndangUndang No. 2 Tahun 2014 Tentang Perubahan atas Undang-Undang No. 30 tahun 2004 Tentang Jabatan Notaris (selanjutnya disingkat UUJNP) yang menentukan bahwa "notaris adalah pejabat umum yang berwenang untuk membuat akta otentik".

Pada pembuatan akta otentik, para pengguna jasa wajib menerangkan keinginan dan tujuan mereka kepada notaris, agar nformasi dan kehendak para pengguna jasa tersebut dapat dituangkan dalam sebuah akta otentik. Akta notaris dibuat bukan hanya sebagai bukti atas kejadian-kejadian hukum yang telah terjadi, tetapi juga digunakan sebagai kekuatan pembuktian. ${ }^{2}$ Akta otentik bisa menjadi bukti bahwa telah adanya perbuatan hukum dan tetap berkekuatan hukum walaupun notaris yang membuat akta itu telah pensiun. Karena itu posisi notaris sangatlah krusial untuk terciptanya kepastian dan perlindungan hukum bagi masyarakat. ${ }^{3}$

Sebagai pejabat Negara dalam melaksanakan jabatannya, notaris tunduk pada UUJN dan UUJNP, sebagaimana ketentuan Pasa1 16 UUJNP yang menentukan: ayat (1) huruf (a) mengatur tentang "kewajiban etik notaris yaitu berkewajiban bertindak dengan amanah, jujur dan tidak memihak", kemudian pada huruf (f), "notaris

\footnotetext{
${ }^{1}$ Darusman, Y. M. (2016). Kedudukan notaris sebagai pejabat pembuat akta otentik dan sebagai pejabat pembuat akta tanah. ADIL: Jurnal Hukum, 7(1), 36-56

2 Fuditia, M. (2018). Pertanggungjawaban Notaris Terhadap Akta Otentik Yang Dibuat Dihadapannya Doctoral dissertation, Fakultas Hukum UNISSULA).

${ }^{3}$ Hendra, R. (2012). Tanggungjawab Notaris Terhadap Akta Otentik Yang Penghadapnya Mempergunakan Identitas Palsu di Kota Pekanbaru. Jurnal Ilmu Hukum Riau, 3(01).
} 
diwajibkan menjaga kerahasiaan mengenai segala sesuatu terkait akta yang dihasilkannya dan segala informasi yang didapatkan untuk pembuatan akta". Pada pemaparan tersebut artinya sebagai notaris harus dapat dipercaya dan dapat merahasiakan tentang akta yang dihasilkannya. ${ }^{4}$ Oleh sebab itu notaris dalam menjalankan wewenangnya harus mengedepankan prinsip kehati-hatian agar akta yang dibuatnya nanti memiliki fakta relevan dan berjalan berdasarkan Undangundang. Notaris sebelum pembuatan akta harus memeriksa semua dokumendokumen yang diserahkan kepadanya, apakah telah lengkap dan sah serta mendengarkan informasi dari para penghadap sebagai landasan pembuatan akta. Contohnya saat para penghadap ke notaris untuk melakukan perbuatan hukum maka notaris wajib melihat berkas asli dari dokumen-dokumen tersebut. Untuk melaksanaan prinsip kehati-hatian, seorang notaris dapat melakukan: ${ }^{5}$

- Pengenalan penghadap dilihat dari identitas

- Mendengarkan keinginan para penghadap

- Memeriksa dokumen

- Menyiapkan rangka akta

- Wajib mencukupi persyaratan dalam pembuatan akta

Notaris bertanggungjawab terhadap akta yang dibuatnya, yaitu bertanggungjawab akan kepastian hari, tanggal, bulan, tahun dan waktu menghadap para pihak; tanda tangan/paraf para pihak, saksi dan notaris, akan tetapi notaris tidak bertanggung jawab terhadap isi akta, karena itu merupakan kesepakatan para pihak, notaris hanya menuangkannya dalam bentuk akta otentik agar memiliki kepastian hukum. Namun realitanya tidak sedikit notaris yang ikut terseret kasus hukum, dikarenakan para pihak memberikan keterangan palsu, data palsu serta tidak sesuai dengan kenyataannya, sehingga notaris dianggap kurang hati-hati dalam membuat akta dan ikut serta dalam melakukan tindak pidana. Contohnya saja pada kejahatan pencucian uang, notaris memiliki andil yang cukup besar dalam mengenali pengguna jasanya dan melaporkannya kepada PPATK, sebagaimana hal ini diatur dalam Peraturan Menteri Hukum dan Hak Asasi Manusia nomor 9 tahun 2017 (selanjutnya disingkat Permenkumham) Pasal 24 ayat (2) yang menentukan, bahwa: $\square$ Notaris wajib melaporkan kepada PPATK mengenai isEp itindakan sebagaimana dimaksud pada ayat (1) sebagai isEPTransaksi Keuangan Mencurigakan."

Permenkumham tersebut memerintahkan kepada notaris untuk melaporkan kepada PPATK apabila diduga terjadi transaksi keuangan mencurigakan yang dilakukan oleh pengguna jasa, jika dalam pembuatan akta, pengguna jasa tersebut menolak untuk mematuhi prinsip mengenali pengguna jasa dan informasi yang disampaikan oleh pengguna jasa diragukan kebenarannya. Sehingga apabila perintah itu dikaitkan dengan Pasal 16 ayat (1) huruf (a) UUJNP yang menentukan bahwa notaris dalam menjalankan kewajibannya, wajib bertindak amanah, jujur, seksama, mandiri, tidak berpihak dan menjaga kepentingan pihak yang terkait dalam perbuatan hukum, dan kemudian dikaitkan pada huruf (f) yaitu mengenai kewajiban notaris

\footnotetext{
${ }^{4}$ Arisaputra, M. I. (2012). Kewajiban Notaris Dalam Menjaga Kerahasiaan Akta Dalam Kaitannya dengan Hak Ingkar Notaris. Perspektif, 17(3), 173-183

5 Rahma, H. F. (2018). Tanggung Jawab Dan akibat Hukum Notaris Dalam Melakukan Identifikasi Dan Verifikasi Data Pengguna Jasa Dalam Nomor 9 Tahun 2017.
} 
untuk merahasiakan isi akta dan keterangan yang diperoleh untuk pembuatan akta tersebut kecuali undang-undang menentukan lain atau lebih dikenal dengan istilah kewajiban ingkar seorang notaris, maka tampak antara aturan-aturan tersebut menjadi tumpang tindih atau terjadi konflik norma antara UUJNP dan Permenkum. UUJNP memerintahkan notaris untuk merahasiakan isi akta atau keterangan terkait pembuatan akta sedangkan Permenkumham memerintahkan notaris untuk memberikan keterangan terkait asal dana pengguna jasa apabila dicurigai adanya indikasi tindak pidana pencucian uang.

Penelitian ilmiah ini melakukan penelusuran terhadap beberapa contoh penelitian terdahulu yang membahas mengenai kewenangan notaris dalam mengenali pengguna jasa, sebagai panduan dan acuan dalam melakukan penelitian ini, yaitu berupa jurnal-jurnal antara lain :

1. Jurnal berjudul “Telaah Terhadap Pergeseran Kewenangan Notaris Setelah Terbitnya Peraturan Menteri Hukum Dan Ham Republik Indonesia Nomor 9 Tahun 2017 Tentang Penerapan Prinsip Mengenali Pengguna Jasa Bagi Notaris" oleh, Indra Prayitno, dari Program Pascasarjana, Fakultas Hukum Universitas Padjajaran, Bandung pada tahun 2017. Rumusan masalah pada penelitian ini yaitu: pertama, membahas mengenai Pergeseran Kewenangan Notaris sebagai Pejabat Umum yang memiliki kewajiban tambahan untuk menentukan kebenaran materil identitas kliennya dengan melakukan identifikasi serta verifikasi identitas dan sumber dana kliennya. Kedua, mengenai konsekuensi yuridis terhadap benturan kebijakan antara kewajiban notaris untuk merahasiakan isi akta yang di atur di dalam Undang-Undang Jabatan Notaris dengan kewajiban notaris untuk melakukan identifikasi dan verifikasi identitas dan sumber dana kliennya serta melaporkan indikasi pelanggaran tindak Pidana Pencucian Uang yang diatur di dalam Peraturan Menteri Hukum dan Hak Asasi Manusia. Kesimpulan yang didapatkan : pertama, Notaris tidak memiliki kewajiban untuk menentukan/memastikan kebenaran materil mengenai identitas penghadap (kliennya), notaris hanya memiliki kewajiban menentukan syarat formal dengan dikenal/diperkenalkannya penghadap (kliennya) kepada notaris sudah cukup untuk menjadi syarat pembuatan akta autentik berdasarkan UUJN. Kedua, ketentuan di dalam PERMENKUMHAM No. 9 Tahun 2017 bertentangan dengan kewajiban menjaga kerahasiaan bagi notaris yang di atur berdasarkan UUJN. Maka yang digunakan adalah UUJN berdasarkan Asas lex superior derogat legi inferior.

2. Jurnal selanjutnya berjudul "Perlindungan Hukum Bagi Notaris Atas Tindak Pidana Pencucian Uang Yang Dialkuak Pleh Penghadapnya" oleh I Made Dermawan, dari Fakultas Hukum Universitas Pamulang, dengan rumusan masalah yaitu mengenai perlindungan hukum terhadap Notaris apabila terjadi tindak pidana pencucian uang oleh penghadapnya. Adapun kesimpulan yang dihasilkan, yaitu perlindungan hukum kepada Notaris dalam hal tindak pidana pencucian uang menurut UUJN pada dasarnya lebih bersifat intern/administrative dan juga adanya hak ingkar.

Oleh sebab pemaparan diatas maka penulis ingin mengambil rumusan masalah tentang kewenangan notaris dalam mengenali pengguna jasa yang diatur dalam PERMENKUMHAM No. 9 Tahun 2017 dan upaya perlindungan hukum terhadap notaris apabila terjadi tindak pidana pencucian uang oleh penghadapnya. 


\section{Metode Penelitian}

Penelitian ini adalah penelitian hukum normatif dengan pendekatan undangundang, teknik mengumpulkan bahan hukumnya menggunakan tehnik bola salju. Spesifikasinya menguraikan aturan-aturan terkait dengan pengaturan dan pelaksanaan kewenangan notaris dalam mengenali pengguna jasa Notaris dalam keterkaitannya terhadap layanan bagi masyarakat dikaitkan dengan aturan yang berlaku di dalam sistem hukum di Indonesia mengenai kewajiban penerapan prinsip mengenali pengguna jasa notaris, sehingga dapat diperoleh kejelasan atas perlindungan hukum bagi notaris apabila terjadi tindak pidana pencucian uang oleh penghadapnya.

\section{Hasil Dan Pembahasan}

\subsection{Kewenangan Notaris Dalam Mengenali Pengguna Jasa}

Notaris berkedudukan dan berperan sangat penting, karena memiliki wewenang untuk membuat alat bukti dalam bentuk akta otentik yang dapat memastikan dengan jelas hak dan kewajiban seseorang sebagai subjek hukum dalam masyarakat, dengan tujuan untuk mewujudkan kepastian hukum bagi masyarakat, agar mencegah adanya masalah hukum dikemudian hari. ${ }^{6}$

Selain kewenangannya tersebut, notaris juga mempunyai kewajiban dan larangan yang perlu dipatuhi dalam melaksanakan tugas jabatannya. Menurut pasal 15 ayat (1) UUJNP yang mengatur kewenangan notaris, yaitu, bahwa "notaris berwenang membuat akta otentik mengenai semua perbuatan, perjanjian, dan penetapan yang diharuskan oleh peraturan perundang-undangan dan/atau yang dikehendaki oleh yang berkepentingan untuk dinyatakan dalam akta autentik, menjamin kepastian tanggal pembuatan akta, menyimpan akta, memberikan grosse, salinan dan kutipan akta, semuanya sepanjang pembuatan akta itu tidak juga ditugaskan atau dikecualikan kepada pejabat lain atau orang lain yang ditetapkan Undang-Undang atau instansi lain."

Selanjutnya pada Pasal 16 ayat (1) huruf f UUJNP yang mengatur tentang kewajiban notaris untuk merahasiakan akta yang dibuat, yaitu: "Notaris berkewajiban untuk merahasiakan segala sesuatu mengenai akta yang dibuatnya dan segala keterangan yang diperoleh guna pembuatan akta sesuai dengan sumpah/ janji jabatan, kecuali undang- undang menentukan lain". Kewajiban notaris untuk merahasiakan semua yang berkenaan dengan Akta dan dokumen lainnya bertujuan untuk melindungi kepentingan semua pihak terkait dengan akta tersebut, sebagimana diatur pada panjelasan Pasal 16 huruf $f$.

Komitmen notaris untuk bertindak amanah dengan menjaga kerahasian yang didapatkan dalam pembuatan akta batasannya hanya undang-undang saja, sehingga notaris dapat menguak rahasia tentang isi akta dan informasi tentang pembuatan akta tersebut kepada pihak tertentu, asalkan didukung oleh peraturan perundang-

\footnotetext{
6 Sjaifurrachman dan Habib Adjie, Aspek Pertanggung Jawab Notaris Dalam Pembuatan Akta, CV Mandar Maju, 2017, hlm. 7
} 
undangan.7 Sebagaimana bunyi Pasa1 50 Kitab Undang-undang Hukum Pidana (selanjutnya disingkat KUHP), yaitu: "Tidaklah dapat dihukum, barang siapa melakukan sesuatu perbuatan untuk melaksanakan suatu peraturan perundangundangan." Namun apabila notaris melanggar aturan tersebut dengan menguak kerahasiaan isi akta tanpa adanya perintah undang-undang, maka notaris dikenakan pidana sebagimana ketentuan Pasal 322 KUHP, " barang siapa dengan sengaja membuka sesuatu rahasia yang ia wajib menyimpannya oleh karena jabatan atau pekerjaan baik yang sekarang maupun yang dahulu, dipidana dengan pidana penjara selama-lamanya sembilan bulan." Menjaga rahasia merupakan kewajiban notaris, apabila notaris menguak informasi yang sehus ia rahasiakan, sedangkan undangundang tidak menyatakannya begitu, maka tindakan notaris seperti ini melanggar ketentuan Pasa1 KUHP tersebut di atas. ${ }^{8}$

Pada perkara di pengadilan ketika notaris diminta menjadi saksi, notaris bisa memohon pembebasan dari kewajiban membuat kesaksian, karena adanya hak ingkar yang dipunyai oleh notaris. Pasal 1909 ayat (3) Kitab Undang-undang Hukum Perdata (KUH Per) yaitu: "siapa saja yang karena kedudukannya, pekerjaannya atau jabatannya diwajibkan undang-undang untuk merahasiakan sesuatu, namun hanya mengenai hal-hal yang dipercayakan kepadanya karena kedudukan, pekerjaan dan jabatannya itu". Hak ingkar notaris untuk keperluan pihak-pihak yang telah memberikan kepercayaannya pada notaris, ${ }^{9}$ sebagaimana undang-undang juga mewajibkan untuk merahasiakannya. Ketentuan hak ingkar tersebut juga diatur pada Pasal 170 ayat (1) Kitab Undang-undang Hukum Acara Pidana (KUHAP) yang mengatur sebagai berikut: "mereka yang karena pekerjaan, harkat martabat atau jabatannya diwajibkan menyimpan rahasia, dapat minta dibebaskan dari kewajiban untuk memberi keterangan sebagai saksi, yaitu tentang hal yang dipercayakan kepada mereka".

Notaris dalam menjalankan tugasnya, wajib memelihara kerahasian dokumen yang dibuatnya dan informasi yang didapatnya pada saat penyusunan akta notaris, kecuali undang-undang meminta sebaliknya, namun disisi berbeda ada ketetapan yang mngharuskan notaris wajib melaporkan kepada PPATK mengenai sispitindakan transaksi keuangan mencurigakan serta notaris diwajibkan menerapkan prinsip kehati-hatian dalam bertransaksi. Prinsip tersebut wajib diterapkan oleh Notaris dan juga profesi lain, hal ini dikarenakan semakin berkembangnya modus pelaku kejahatan yang menggunakan ketentuan kerahasian profesi yang telah diatur daam hukum positif guna menutupi dan menyamarkan kejahatan yang dilakukan, padahal profesi Notaris adalah profesi terhormat yang bekerja untuk melayani masyarakat dibidang hukum perdata dan tidak seharusnya menjadi sarana kejahatan TPPU oleh pelaku yang tentunya akan merusak nama baik profesi Notaris.

Mengenali pengguna jasa adalah asas terpenting Notaris, sebagaimana diatur pada PERMENKUMHAM Nomor 9 Tahun 2017, antara lain pada:

\footnotetext{
7 Ekaputri, A. R., \& Sesung, R. (2018). Kewajiban Ingkar Notaris Untuk Menjaga Kerahasiaan Jabatan Dalam Proses Peradilan. Jurnal Jatiswara, 33(2).

8 Ibid., hlm. 90

9 Habib Adjie, Hukum Notaris Indonesia Tafsir Tematik Terhadap UU No 30 Tahun 2004 Tentang Jabatan Notaris, PT Refika Aditama, Bandung, hlm. 86
} 
1. Pasal 2 ayat (1) dan ayat (2), "Notaris wajib menerapkan prinsip mengenali pengguna jasa dengan mengidentifikasi pengguna jasa; meverifkasi pengguna jasa; dan melakukan pemantauan terhadap transaksi pengguna jasa".

2. Pasal 4 ayat (1) dan ayat (2), "dalam menerapkan prinsip mengenali pengguna jasa notaris wajib: memiliki kebijakan dan prosedur untuk mengelola dan mengurangi risiko pencucian uang dan/ atau pendanaan terorisme yang diidentifikasi sesuai dengan penilaian risiko; melakukan penilaian resiko dan mengelompokkan pengguna jasa berdasarkan tingkat risiko terjadinya tindak pidana pencucian uang dan tindak pidana pendanaan terorisme berdasarkan analisis terhadap profil; bisnis; negara; produk".

Selain pelaksanaan dasar mengidentifiasi pemakai pelayanan, notaris juga berwenang seperti diatur pada Pasal 5 PERMENKUMHAM, yaitu: "notaris dilarang untuk membuka atau memelihara rekening anonim atau rekening yang menggunakan nama fiktif, termasuk rekening bukti hubungan usaha antara notaris dengan pengguna jasa", dan pada Pasal 11 huruf (c), "notaris diwajibkan juga untuk mengidentifikasi penghadap melalui pengumpulan informasi pengguna jasa dan wajib didukung dengan pengambilan spesimen tandatangan".

Kewajiban tambahan bagi notaris yang diatur dalam PERMENKUMHAM tersebut, sebagai peraturan pelaksana kewenangan notaris yang diatur dalam Pasal 39 ayat (2) UUJNP, "penghadap harus dikenal oleh notaris atau diperkenalkan kepadanya oleh 2 (dua) orang saksi pengenal yang berumur paling sedikit 18 (delapan belas) tahun atau telah menikah dan cakap melakukan perbuatan hukum atau diperkenalkan oleh 2 (dua) penghadap lainnya", KTP atau identitas lainnya hanyalah pendukung untuk pembuatan aktanya.

Mengenali pengguna jasa notaris juga diatur dalam Undang-Undang Nomor 8 Tahun 2010 tentang Pencegahan dan Pemberantas Tindak Pidana Pencucian Uang (UUTPPU), yaitu pada:

1. Pasal 18 ayat (2), "pihak Pelapor wajib menerapkan prinsip mengenali pengguna jasa yang ditetapkan oleh setiap lembaga Pengawas dan Pengatur sebagaimana yang dimaksud dalam ayat (1)".

2 Pasal 18 ayat (3), "Kewajiban menerapkan prinsip mengenali pengguna jasa sebagaimana dimaksud pada butir 1 diatas, dilakukan pada saat: melakukan hubungan usaha dengan pengguna jasa; terdapat transaksi keuangan dengan mata uang rupiah dan/ atau mata uang asing yang nilainya paling sedikit atau setara dengan Rp. 100.000.000,- (seratus juta rupiah); terdapat transaksi keuangan mencurigakan yang terkait tindak pidana pencucian uang dan tindak pidana pendanaan terorisme; atau pihak pelapor meragukan kebenaran informasi dari pengguna jasa".

Selanjutnya dalam Peraturan Pemerintah Nomor 43 Tahun 2015 tentang Pihak Pelapor Dalam Pencegahan dan Pemberantasan Tindak Pidana Pencucian Uang (selanjutnya disingkat PP 43/2015) Pasal 8 mengatur, "bahwa notaris selaku pihak pelapor berkewajiban menyampaikan laporan transaksi keuangan mencurigakan kepada PPATK untuk kepentingan atau untuk dan atas nama pengguna jasa, mengenai pembelian dan penjualan properti; pengelolaan terhadap uang efek, dan/ atau produk jasa keuangan lainnya; pengelolaan rekening giro, rekening tabungan, 
rekening deposito, dan/ atau rekening efek; pengoperasian dan pengelolaan perusahaan; dan/ atau pendirian, pembelian, dan penjualan badan hukum".

Terhadap penghadap, yang dipandang transaksi yang akan dilakukannya mencurigakan, maka Notaris berkewajiban meminta dokumen tambahan. Notaris wajib juga menolak permintaan para pihak dalam pembuatan akta, bila para pihak tersebut tidak mau menyerahkan dokumen yang diminta oleh notaris. Notaris diwajibkan membatalkan hubungan jika:

1) Pengguna jasa tidak mau tunduk pada prinsip mengenali pengguna jasa; atau

2) Notaris ragu akan keterangan yang diberikan oleh pengguna jasa. ${ }^{10}$

Notaris sebagai pihak pelapor dalam menjalankan kewajiban pelaporan terkait adanya transaksi keuangan yang mencurigakan tidaklah melanggar Undang-Undang No. 2 Tahun 2014 Tentang Perubahan atas Undang-Undang No. 30 tahun 2004 Tentang Jabatan Notaris menentukan, karena dalam hal ini notaris dilindungi oleh undangundang, sebagaimana ketentuan Pasal 28 UUTTPU yang menentukan, bahwa "Pelaksanaan kewajiban pelaporan oleh Pihak Pelapor dikecualikan dari ketentuan kerahasian yang berlaku bagi Pihak Pelapor bersangkutan", akan tetapi jika dengan sengaja membogkar kerahasiaan yang wajib dijaganya karena jabatan, maka diancam pidana sesuai ketentuan Pasal 322 KUH Pidana. Dengan demikian, pelaporan oleh notaris atas transaksi keuangan para pihak yang diragukan kepada PPATK, bukan berarti bahwa telah terjadi kejahatan pencucian uang melalui pembuatan aktanya. PPATK dalam hal ini yang berkewajiban untuk menyimpulkan berdasarkan analisis dari profil atau karasteritik pengguna jasa, apakah transaksi yang dilaporkan tersebut, adalah wajar atau tidak.

Pada pembahasan ini menggunakan Teori Kewenangan. Kata kewenangan berasal dari kata dasar wewenang yang diartikan sebagai hal berwenang, hak dan kekuasaan yang dipunyai untuk melakukan sesuatu. Kewenanangan adalah kekuasaan formal, kekuasaan yang diberikan oleh Undang- Undang atau dari kekuasaan eksekutif administrasi. Secara yuridis pengertian wewenang adalah kemampuan yang diberikan oleh peraturan perundang-undangan untuk menimbulkan akibat-akibat hukum ${ }^{19}$. Sedangkan pengertian wewenang menurut H.D.Stoud adalah "bevoegheid wet kan worden omscrevenals het geheel van bestuurechttelijke bevoegheden door publiekrechtelijke rechtssubjecten in het bestuurechttelijke rechtsverkeer" bahwa wewenang dapat dijelaskan sebagai keseluruhan aturan-aturan yang berkenaan dengan perolehan dan penggunaan wewenang pemerintah oleh subjek hukum publik dalam hukum publik ${ }^{20}$. Teori kewenangan di atas jika dikaitkan dengan Rumusan masalah no 1, maka mengenali pengguna jasa, merupakan kekuasaan yg dimiliki oleh notaris yang diberikan oleh undang undang untuk dapat mengetahui layak tidaknya pengguna jasa melakukan perbuatan hukum.

${ }^{10}$ https:/ /irmadevita.com/2017prinsip-prinsip-pengenalan-pengguna-jasa-notaris/ 


\subsubsection{Perlindungan Hukum Terhadap Notaris Jika Pengguna Jasanya Melakukan Tindak Pidana Pencucian Uang}

Pada dasarnya jabatan notaris dikategorikan sebagai pranata hukum perdata, tetapi notaris tetap bersinggungan dengan pranata hukum pidana oleh sebab itu jabatan notaris juga harus mendapatkan pengamanan tersirat pada Pasa1 66 UndangUndang No. 2 Tahun 2014 Tentang Perubahan atas Undanng-Undang No. 30 tahun 2004 Tentang Jabatan Notaris yang menetukan: “Untuk kepentingan proses peradilan, penyidik, penuntut umum, atau hakim dengan persetujuan Majelis Kehormatan notaris berwenang: mengambil fotokopi Minuta Akta dan/atau surat-surat yang dilekatkan pada Minuta Kata atau Protokol Notaris dalam penyimpanan Notaris; dan memanggil notaris untuk hadir dalam pemeriksaan yang berkaitan dengan Akta atau Protokol notaris yang berada dalam penyimpanan notaris".

Terkait pemanggilan notaris dalam perkara di pengadilan, maka harus ada persetujuan Majelis Kehormatan Notaris (MKN) terlebih dahulu. MKN bertujuan melakukan pengawasan agar notaris ketika memenuhi jabatannya sesuai dengan aturan dalam UUJNP yang menentukan dan juga untuk melindungi notaris dalam menuhi jabatan. Perlindungan terhadap notaris ini disebut Hak Ingkar, yang berguna untuk kepentingan para pengguna jasa notaris.

Hak ingkar yaitu suatu hak untuk tidak menyampaikan informasi apapun. Hak ingkar adalah bentuk kekebalan notaris terhadap hukum ketika menjadi saksi dalam proses di Pengadilan untuk tidak membagikan informasi apapun terkait akta yang dibuatnya. ${ }^{11}$

Pasal 170 KUHAP menegaskan bahwa:

(1) Jabatan yang ditentukan oleh Undang-undang adanya kewajiban untuk menyimpan rahasia, maka dapat dimintakan untuk tidak menjadi saksi.

(2) Dan hakim akan menentukan segala alasan untuk permintaan tersebut.sah atau tidak.

Kemudian pada Pasal 1909 KUHPerdata, "semua orang yang cakap untuk menjadi saksi, diharuskan memberikan kesaksian di muka hakim. Namun dapatlah meminta dibebaskan dari kewajibannya memberikan kesaksian". Pada tersebut di atas juga mengatur bahwa "segala siapa yang karena kedudukannya, pekerjaannya atau jabatannya menurut undang-undang diwajibkan merahasiakan sesuatu, namun hanyalah semata-mata mengenai hal-hal yang pengetahuannya dipercayakan kepadanya demikian".

Hakim Lilik Mulyadi berpendapat ${ }^{12}$ "bahwa aspek ini yang dibuat oleh seorang Notaris tersebut adalah bersifat akta otentik dan kebenaran yang diungkapkan adalah bersifat kebenaran formal, berlainan dengan yang ada dalam hukum acara pidana, dimana hakim mencari kebenaran materiil, ini tidak berarti bahwa dalam acara perdata hakim mencara kebenaran yang setengah-setengah atau palsu". Hakim dalam perkara perdata melihat perkara lebih kepada seberapa luas pemeriksaan, jadi tidak

11 Marjon, D. (2017). Aplikasi Kode Etik Hak Ingkar Notaris Sebagai Saksi Dalam Perkara Perdata Dan Pidana. Jurnal Notariil, 1(1), 88-108.

12 M. Nurung, "Notaris Tidak Tepat Dijadikan Saksi Hukum Perdata", 2006, Majalah Renvoi 12 Edisi Mei, hlm. 68 . 
melihat kepada isi, hakim hanya mencari kebenaran formil saja, sedangkan pada perkara pidana yang dilihat adalah kebenaran materi. Pada perkara pidana di Pengadilan untuk tercapainya kebenaran materiil, maka atas persetujuan Majelis Kehormatan Notaris, notaris wajib hadir untuk bersaksi mengenai yang diketahuinya tentang suatu kejadian agar perkara tersebut menjadi jelas. Namun, jika kesaksian tersebut berkaitan dengan kerahasian suatu akta yang tidak mungkin untuk dibuka dalam persidangan, maka notaris lebih baik menolak atau mundur sebagai saksi, sebagimana ketentuan tersebut diatur pada Pasal 170 ayat (1) KUHP dan Pasal 1909 ayat (2) KUH Perdata.

Penerapan hak ingkar tidak hanya diterapkan pada kesaksian secara menyeluruh atau pada setiap pertanyaan, tetapi bisa juga terhadap beberapa pertanyaan tertentu. Sehingga penolakan untuk menjawab atas pertanyaan tertentu bisa mempergunakan hak ingkar, jika ada hubungannya dengan materi atau isi akta. Namun penggunaan hak ingkar tersebut dikecualikan sebagaimana ketentuan Pasal 16 ayat (1) huruf f dan Pasal 54 UUJNP yang menentukan, yaitu: "kecuali Undang Undang menentukan lain". Sehingga ketentuan tersebut menegaskan "notaris tidak dapat menggunakan Hak Ingkar jika akta yang dibuatnya berkaitan dengan tindak pidana korupsi", sebagaimana Pasal 36 Undang-Undang Nomor 31 Tahun 1999 tentang Pemberantasan Tindak Pidana Korupsi yang menentukan, bahwa "kewajiban memberikan kesaksian sebagaimana dimaksud dalam Pasal 35 berlaku juga terhadap mereka yang menurut pekerjaan, harkat dan martabat atau jabatannya diwajibkan menyimpan rahasia, kecuali petugas agama yang menurut keyakinannya harus menyimpan rahasia".

Notaris dapat mempergunakan hak ingkar jika diperiksa oleh instansi dalam upayanya untuk mendapatkan informasi dari Notaris, terkait aktanya. ${ }^{13}$ Hak ingkar terhadap Notaris bertujuan untuk melindungi notaris dan menjamin kepastian hukum bagi profesi Notaris dalam menjalankan tugasnya yang diberikan UUJN dan Kode Etik, baik menurut hukum maupun moral dan etika profesi dan untuk kepentingan umum.

Terkait dengan pemberantasan tindak pidana korupsi, jika dilihat dari sudut pandang UUJN, maka aturan pada UUJN yang mengatur kewajiban melapor kepada penegak hukum jika terjadi transaksi keuangan yang patut dicurigai terhadap pengguna jasanya adalah gagasan dari Notaris itu sendiri, dengan ketentuan apabila hendak melakukan pelaporan, maka Notaris sebagai pelapor harus menaruh jabatannya sebagai pejabat Publik atau Notaris/PPAT dan berkedudukan sebagai warga biasa, notaris dalam perbuatan ini juga harus mendapatkan perlindungan hukum dari negara beserta keluarganya.

Informan dan saksi ketika adanya tindak pidana pencucian uang, maka undang-undang memberikan perlindungan sebagiamana diatur dalam UUTPPU (Undang-Undang Nomor 8 tahun 2010 tentang Pencegahan dan Pemberantasan Tindak Pidana Pencucian Uang). Bentuk perlindungan yang diberikan adalah "pertama, menjaga kerahasian identitas dari pelapor, tujuannya agar pelapor merasa aman dari pelaku TPPU yang bisa membahayakan jiwanya, keluarga dan harta benda miliknya. Kedua, adalah terbebasnya pelapor dari segala tuntutan hukum baik perdata maupun pidana terhadap laporan yang diberikannya kepada penegak hukum".

13 Ibid 
UUTPPU menegaskan “Jika identitas pelapor terungkap, maka menurut pelapor atau ahli warisnya dapat menuntut penggantian atas kerugian yang timbul kepada pihak yang membocorkan identitas pelapor".

Selanjutnya Peraturan Pemerintah Nomor 57 Tahun 2003 tentang Tata Cara Perlindungan Khusus Bagi Pelapor dan Saksi Tindak Pidana Pencucian Uang, mengatur juga perlindungan bagi pelapor dan saksi tindak pidana pencucian uang yang secara spesifik diatur dalam Pasal 2 yang menetukan, bahwa "setiap pelapor dan saksi dalam perkara tindak pidana pencucian uang wajib diberikan perlindungan khusus baik sebelum, selama maupun sesudah proses pemeriksaan perkara. Bentuk perlindungan khusus yang dimaksud adalah perlindungan atas keamanan pribadi dari ancaman fisik dan mental, perlindungan terhadap harta, perlindungan berupa kerahasiaan dan penyamaran identitas, dan memberikan keterangan tanpa bertatap muka (konfrontasi) dengan tersangka atau terdakwa pada setiap tingkatan pemeriksaan perkara".

Pada pembahasan masalah ini menggunakan Teori Perlindungan Hukum. Menurut Fitzgerald sebagaimana dikutip Satjipto Raharjo, awal mula dari munculnya teori perlindungan hukum ini menyebutkan bahwa hukum itu bersumber dari Tuhan yang bersifat universal dan abadi, serta antara hukum dan moral tidak boleh dipisahkan. Para penganut aliran ini memandang bahwa hukum dan moral adalah cerminan dan aturan secara internal dan eksternal dari kehidupan manusia yang diwujudkan melalui hukum dan moral. ${ }^{1}$ Menurut Satjito Rahardjo perlindungan hukum adalah adanya upaya melindungi kepentingan seseorang dengan cara mengalokasikan suatu Hak Asasi Manusia kekuasaan kepadanya untuk bertindak dalam rangka kepentingannya tersebut. Perlindungan hukum lahir dari suatu ketentuan hukum dan segala peraturan hukum yang diberikan oleh masyarakat yang pada dasarnya merupakan kesepakatan masyarakat tersebut untuk mengatur hubungan prilaku antara anggota-anggota masyarakat dan antara perseorangan dengan pemerintah yang dianggap mewakili kepentingan masyarakat. ${ }^{2}$ Dengan hadirnya hukum dalam kehidupan bermasyarakat, berguna untuk mengintegrasikan dan mengkoordinasikan kepentingan-kepentingan yang biasa bertentangan antara satu sama lain. Maka dar itu, hukum harus bisa mengintegrasikannya sehinggabenturan-benturan kepentingan itu dapat ditekan seminimal mungkin. Dengan kata lain perlindungan hukum terhadap notaris sebagai suatu gambaran dari fungsi hukum, yaitu konsep dimana hukum dapat memberikan suatu keadilan, ketertiban, kepastian, kemanfaatan dan kedamaian. Perlindungan hukum terhadap notaris dimana peraturan memberi perlindungan terhadap notaris guna menjaga sumpah janji jabatannya.

\section{Kesimpulan}

Hasil penelitian ini menyimpulkan bahwa: "pertama, notaris wajib menerapkan prinsip mengenali pengguna jasa, apabila ada ketidaksesuaian atau diduga adanya tindak pidana pencucian uang. Notaris juga wajib melaporkan pengguna jasa tersebut kepada PPATK jika diduga transaksi tersebut mencurigakan. Tindakan yang dilakukan notaris ini tidaklah melanggar ketentuan Pasal 16 ayat (1) hurup f UUJNP, karena tindakan yang dilakukan tersebut telah diatur pada Pasal 28 UUTTPU. Kedua, perlindungan hukum kepada Notaris terkait pemanggilan notaris dalam perkara di pengadilan, maka harus ada persetujuan Majelis Kehormatan Notaris (MKN) terlebih 
dahulu dan juga notaris dapat menggunakan hak ingkar jika ada hubungannya dengan materi atau isi akta.

\section{DAFTAR PUSTAKA}

\section{BUKU:}

Habib Adjie, Hukum Notaris Indonesia Tafsir Tematik Terhadap UU No.30 Tahun 2004 Tentang Jabatan Notaris. Bandung: PT Refika Aditama.

Indrohato. (1994). Asas-Asas Umum Pemerintahan yang baik, dalam Paulus Efendie Lotulung, Himpunan Makalah Asas-Asas Umum Pemerintahan yang baik. Bandung : Citra Aditya Bakti.

M. Nurung. (2006).“Notaris Tidak Tepat Dijadika Saksi Hukum Perdata”. Majalah Renvo 12 Edisi Mei.

Satjipto Raharjo. (2000). Ilmu Hukum. Bandung: PT. Citra Aditya Bakti.

Sjaifurrachman dan Habib Adjie. (2017). Aspek Pertanggung Jawab Notaris Dalam Pembuatan Akta. Bandung: CV Mandar Maju.

Stout HD. (2004). de Betekenissen van de wet, dalam Irfan Fachruddin, Pengawasan Peradilan Administrasi terhadap Tindakan Pemerintah. Bandung: Alumni.

\section{JURNAL :}

Arisaputra, M. I. (2012). Kewajiban Notaris Dalam Menjaga Kerahasiaan Akta Dalam Kaitannya dengan Hak Ingkar Notaris. Perspektif, 17(3).

Darusman, Y. M. (2016). Kedudukan notaris sebagai pejabat pembuat akta otentik dan sebagai pejabat pembuat akta tanah. ADIL: Jurnal Hukum, 7(1).

Ekaputri, A. R., \& Sesung, R. (2018). Kewajiban Ingkar Notaris Untuk Menjaga Kerahasiaan Jabatan Dalam Proses Peradilan. Jurnal Jatiswara, 33(2).

Fuditia, M. (2018). Pertanggungjawaban Notaris Terhadap Akta Otentik Yang Dibuat Dihadapannya, (Doctoral dissertation, Fakultas Hukum UNISSULA).

Hendra, R.(2012). Tanggungjawab Notaris Terhadap Akta Otentik Yang Penghadanya Mempergunakan Identitas Palsu di Kota Pekanbaru. Jurnal Ilmu Hukum Riau, 3(01).

Made Darmawan, I. (2017). Perlindungan Hukum Bagi Notaris Atas Tindak Pidana Pencucian Uang Yang Dilakukan Oleh Penghadapnya. Jurnal Surya Kencana Satu: Dinamika Masalah Hukum dan Keadilan, 7(1).

Marjon, D. (2017). Aplikasi Kode Etik Hak Ingkar Notaris Sebagai Saksi Dalam Perkara Perdata Dan Pidana. Jurnal Notariil, 1(1).

Prayitno, I. (2017). Telaah Terhadap Pergeseran Kewenangan Notaris Setelah Terbitnya Peraturan Menteri Hukum Dan Ham Republik Indonesia Nomor 9 Tahun 2017 Tentang Penerapan Prinsip Mengenali Pengguna Jasa Bagi Notaris.ACTA DIURNAL Jurnal Ilmu Hukum Kenotariatan, 1(1).

Rahma, H. F. (2018). Tanggung Jawab Dan Akibat Hukum Notaris Dalam Melakukan Identifikasi Dan Verfikasi Data Pengguna Jasa Dalam Permnekumham Nomor 9 Tahun 2017. 
P-ISSN: 2502-8960, E-ISSN: 2502-7573

\section{INTERNET:}

https://irmadevita.com/2017prinsip-prinsip-pengenalan-pengguna-jasa-notaris/ $\mathrm{k}$ 